\title{
PRECIPITATIVE RE-EXTRACTION OF URANIUM(VI) FROM ORGANIC SOLUTIONS OF METHYLTRIOCTILAMMONIUM URANYL PEROXO-CARBONATE COMPLEXES
}

\author{
S.O. Frankiv' ${ }^{1}$ A.V. Boyarintsev ${ }^{1,2 *}$, S.I. Stepanov ${ }^{1,2}$ \\ ${ }^{1}$ Mendeleev University of Chemical Technology, Moscow, Russia \\ ${ }^{2}$ Ozersk Institute of Technology, Ozersk, Russia
}

\begin{abstract}
The article discusses the results of the uranium(VI) re-extraction(stripping) from the methyltrioctilammonium organic phase loaded by uranium(VI) peroxo-carbonate species using ammonium carbonate and ammonium bicarbonate aqueous solutions or gaseous carbon dioxide. Conditions for 97-99\% re-extraction of uranium (VI) to obtain crystalline ammonium uranyl carbonate with structure $\left(\mathrm{NH}_{4}\right)_{4}\left[\mathrm{UO}_{2}\left(\mathrm{CO}_{3}\right)_{3}\right]$ were determined.
\end{abstract}

Key words: Uranium(VI), peroxo-carbonate species, ammonium uranyl carbonate, solvent extraction, re-extraction, stripping, methyltrioctilammonium carbonate, ammonium carbonate, ammonium bicarbonate, carbon dioxide

\section{INTRODUCTION}

In 2008, the CARBEX (CARBonate EXtraction) concept was formulated [1]. This hydrochemical method of the spent nuclear fuel (SNF) reprocessing in carbonate media using solvent extraction (SE) technique for separation and purification of uranium and plutonium from fission products (FPs). The CARBEX process is based on the development of the oxidative dissolution of $\mathrm{UO}_{2}, \mathrm{U}_{3} \mathrm{O}_{8}$, and $\mathrm{UO}_{2}$-based SNF in carbonate or carbonate-alkaline media [2]-[5], as well as on the development of the effective SE techniques for separation and purification of uranium and plutonium from carbonate media using quaternary ammonium compounds (QACs) [6]. In the CARBEX process, all technological operations, including SE processing, are carried out using carbonate media. The most suitable solvents for carbonate media are QACs, in particular of methyltrioctylammonium (MTOA with structure - $\left.\mathrm{CH}_{3}\left(\mathrm{C}_{8} \mathrm{H}_{17}\right)_{3} \mathrm{~N}^{+}\right)$carbonate or methyltrialkylammonium (MTAA with structure $\left.\mathrm{CH}_{3}\left(\mathrm{C}_{7} \mathrm{H}_{15}-\mathrm{C}_{9} \mathrm{H}_{19}\right)_{3} \mathrm{~N}^{+}\right)$carbonate, which have high radiation resistance. Chlorides of QACs, which are the basis for the preparation of MTOA or MTAA carbonates, are manufactured on an industrial scale.

An important stage of the SE scheme for the processing of $\mathrm{U} / \mathrm{Pu}$-containing carbonate solutions in the CARBEX process is the precipitative reextraction(stripping) of uranium and plutonium in the form of crystalline carbonate compounds mixture. Direct calcination of such mixtures in a reducing atmosphere makes it possible to obtain $\mathrm{UO}_{2}$ and $\mathrm{PuO}_{2}$ with high purity, which can be used for fabrication/refabrication of mixed oxide (MOX) fuel. The possibility of obtaining mixed uranium-plutonium products and exception production of the pure plutonium compounds make it possible to fulfill the requirements for the non-proliferation of fissile materials.
The re-extraction of uranium and plutonium in the CARBEX process may be in conventional option (liquid/liquid two-phase system) or liquid/liquid/solid three-phase system with precipitation of crystalline ammonium uranyl(plutonyl) carbonate $\left(\mathrm{NH}_{4}\right)_{4}\left[\mathrm{U}(\mathrm{Pu}) \mathrm{O}_{2}\left(\mathrm{CO}_{3}\right)_{3}\right](\mathrm{AU}(\mathrm{Pu}) \mathrm{C})$. The combination of SE cycle with selective re-extraction of uranium and plutonium in the form of $\mathrm{AU}(\mathrm{Pu}) \mathrm{C}$ crystals allows to achieving additional purification from impurities, including from FPs and, provide a significant improvement in the quality of the carbonate powders from which high purity oxides of U(IV) and $\mathrm{Pu}(\mathrm{IV})$ can be obtained.

Since precipitative re-extraction combines the processes of uranium and plutonium separation from organic phase with their deposition, this reduces the number of processing operations and to some extent reduces the volume of liquid waste.

For re-extraction of $\mathrm{U}(\mathrm{Pu})$ from the loaded organic phases in the CARBEX process, the aqueous solutions of ammonium carbonate $\left(\left(\mathrm{NH}_{4}\right)_{2} \mathrm{CO}_{3}\right)$ and ammonium bicarbonate $\left(\mathrm{NH}_{4} \mathrm{HCO}_{3}\right)$ or mixtures thereof can be used. In the process of $\mathrm{U}(\mathrm{VI})$ precipitative reextraction, a three-phase system is formed: organic phase - carbonate solution - AUC crystals. The AUC crystals are typically readily separated from the depleted organic phase and carbonate strip liquor. The carbonate mother liquor after AUC crystals removal can be recycled to the re-extraction stage.

The degree of uranium deposition in the precipitative re-extraction process is determined by the solubility of AUC crystals in carbonate solutions. The precipitative re-extraction conditions are usually selected such that the solubility of the carbonate complex is not greater than $3-5 \mathrm{gU} / \mathrm{L}$ and crystals formation takes place over at least $60 \mathrm{~min}$. Only slow AUC crystals growth provides their required size (not less than $10 \mu \mathrm{m})$. The solubility of AUC in aqueous solutions of $\left(\mathrm{NH}_{4}\right)_{2} \mathrm{CO}_{3}$ and $\mathrm{NH}_{4} \mathrm{HCO}_{3}$ increases with

*aboyarincev@muctr.ru 
the increase of temperature and decreases with the increase of salts concentration in carbonate solutions.

Precipitative re-extraction process is proposed for the separation of uranium [7,8], plutonium, and neptunium from the organic phase with neutral organophosphorus compounds (usually tri- $n$-butyl phosphate), alkyl phosphoric acids, and tertiary amines or their mixtures. In the SNF reprocessing technology, precipitative re-extraction is carried out after the SE separation and purification stage of fissile materials from impurities [9]. For precipitative reextraction of metals, aqueous solutions of oxalic acid or $\left(\mathrm{NH}_{4}\right)_{2} \mathrm{CO}_{3}$ are usually used [7]-[9]. At the same time, it is possible to precipitate up to $99.9 \%$ of uranium, plutonium, and neptunium. After separation from the mother liquor, the crystalline carbonate precipitate is washed from the organic phase. The washed and dried carbonate precipitate is used to obtain a solid solution of uranium and plutonium dioxides. The precipitative re-extraction of uranium by $\left(\mathrm{NH}_{4}\right)_{2} \mathrm{CO}_{3}$ aqueous solutions (with a concentration of not more than $200 \mathrm{~g} / \mathrm{L}$ ) with obtaining of crystalline AUC (with crystals size about $60-80 \mu \mathrm{m}$ ) is carried out at the $\mathrm{CO}_{3}{ }^{2-}: \mathrm{UO}_{2}{ }^{2+}$ ratio equal to $3: 1$ and phase contact time is not less than 20-25 min [10]. An important efficiency factor of the precipitative re-extraction process is not only a high degree of metal recovery from the organic phase but also a high-value degree of deposition of the valuable component.

To solve the problems of implementation of SNF reprocessing technology in carbonate media, it is necessary to carry out studies, in particular, regarding the development of a scheme for the extraction and purification of uranium and plutonium from carbonate media in the loading/scrubbing/stripping cycle. One important step in developing such a scheme is to determine the optimal parameters of the re-extraction process.

The purpose of this article was to study and optimization the re-extraction of U(VI) as crystalline carbonate compounds from the organic phase of methyltrioctylammonium under conditions of solvent extraction separation and purification of carbonate solutions after the oxidative dissolution of SNF in the CARBEX process.

\section{MATERIALS AND METHODS}

Solid salts $\mathrm{Na}_{2} \mathrm{CO}_{3},\left(\mathrm{NH}_{4}\right)_{2} \mathrm{CO}_{3}, \mathrm{NH}_{4} \mathrm{HCO}_{3}$, and $35 \%$ aqueous solution of $\mathrm{H}_{2} \mathrm{O}_{2}$ of the chemically pure grade were used. Initial U(VI) compounds such as uranium peroxide - $\mathrm{UO}_{4} \cdot 4 \mathrm{H}_{2} \mathrm{O}$ and sodium tricarbonatouranylate $\quad-\mathrm{Na}_{4}\left[\mathrm{UO}_{2}\left(\mathrm{CO}_{3}\right)_{3}\right]$ were synthesized by precipitation from the concentrated aqueous solution of $\mathrm{UO}_{2}\left(\mathrm{NO}_{3}\right)_{3}$ [11]. Aqueous solutions of $\mathrm{UO}_{2}\left(\mathrm{NO}_{3}\right)_{3}$ were obtained by dissolution of chemically pure $\mathrm{UO}_{2}\left(\mathrm{NO}_{3}\right)_{3} \cdot 6 \mathrm{H}_{2} \mathrm{O}$ in the distilled water. The composition of the uranyl peroxide and sodium tricarbonatouranylate powders was confirmed by x-ray diffraction (XRD), Figure 1.

Carbonate solutions containing U(VI) in the form of mixed peroxo-carbonate species were prepared by dissolution of the crystalline $\mathrm{Na}_{4}\left[\mathrm{UO}_{2}\left(\mathrm{CO}_{3}\right)_{3}\right]$ or $\mathrm{UO}_{2} \mathrm{O}_{2} \cdot 4 \mathrm{H}_{2} \mathrm{O}$ in $1.0 \mathrm{~mol} / \mathrm{L}$ solutions of $\mathrm{H}_{2} \mathrm{O}_{2}$ or
$\mathrm{Na}_{2} \mathrm{CO}_{3}$, respectively. The formation of mixed peroxocarbonate species of U(VI) can be described by the following chemical equations:

$$
\mathrm{UO}_{2} \mathrm{O}_{2(\mathrm{~s})}+2 \mathrm{Na}_{2} \mathrm{CO}_{3}(\mathrm{aq}) \rightarrow \mathrm{Na}_{4}\left[\mathrm{UO}_{2}\left(\mathrm{O}_{2}\right)\left(\mathrm{CO}_{3}\right)_{2}\right]_{(\mathrm{aq})}
$$

$\mathrm{Na}_{4}\left[\mathrm{UO}_{2}\left(\mathrm{CO}_{3}\right)_{3}\right]_{(\mathrm{s})}+x \mathrm{H}_{2} \mathrm{O}_{2}(\mathrm{aq}) \leftrightarrow$

$\leftrightarrow \mathrm{Na}_{4}\left[\mathrm{UO}_{2}\left(\mathrm{O}_{2}\right)_{x}\left(\mathrm{CO}_{3}\right)_{3-x}\right]_{(\mathrm{aq})}+2 x \mathrm{H}^{+}{ }_{(\mathrm{aq})}+x \mathrm{CO}_{3}{ }^{2-}{ }_{(\mathrm{aq})}$

where $x=1$ or 2 .

In $\mathrm{Na}_{2} \mathrm{CO}_{3}-\mathrm{H}_{2} \mathrm{O}_{2}$ aqueous solutions, the formation of polynuclear species of U(VI): $\left[\left(\mathrm{UO}_{2}\right)_{2}\left(\mathrm{O}_{2}\right)\left(\mathrm{CO}_{3}\right)_{4}\right]^{6-}$ or $\left[\left(\mathrm{UO}_{2}\right)_{3}\left(\mathrm{O}_{2}\right)_{2}\left(\mathrm{CO}_{3}\right)_{4}\right]^{6-}$ can also occur $[12]-[14]$.

Solvent extraction and re-extraction procedures were carried out in 10-25 mL glass separation funnels at $25 \pm 2^{\circ} \mathrm{C}$. The phase mixing time was $20-120 \mathrm{~min}$. Methyltrioctylammonium carbonate as the solvent was used. This compound was synthesized by the original technique. Toluene of the chemically pure grade was used as a diluent. Solvent extraction of U(VI) was carried out using $0.5 \mathrm{~mol} / \mathrm{L}$ solution of MTOA carbonate in toluene.
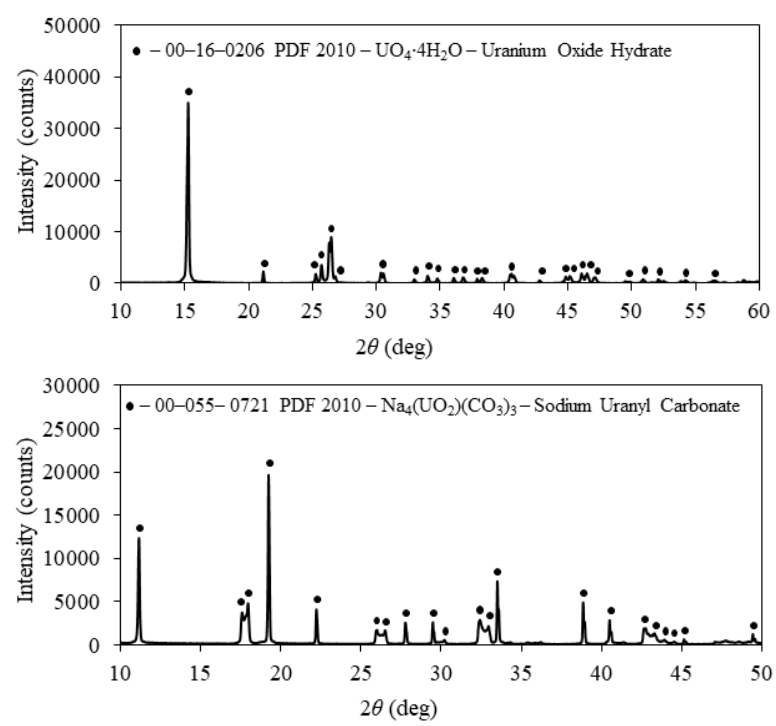

Figure 1. XRD patterns of $\mathrm{UO}_{4} \cdot 4 \mathrm{H}_{2} \mathrm{O}$ and $\mathrm{Na}_{4}\left[\mathrm{UO}_{2}\left(\mathrm{CO}_{3}\right)_{3}\right]$ powders

The re-extraction yield of U(VI) (Re(U(VI))) was determined from the decrease in the U(VI) concentration in the organic phase: $\operatorname{Re}(\mathrm{U}(\mathrm{VI}))=$ $\left.\left(\left([\mathrm{U}(\mathrm{VI})]_{\text {ORG.INIT }}\right)-[\mathrm{U}(\mathrm{VI})]_{\text {ORG.EQ }}\right) /[\mathrm{U}(\mathrm{VI})]_{\text {ORG.INIT }}\right) \cdot 10$ $\mathrm{o}$, where $[\mathrm{U}(\mathrm{VI})]_{\text {ORG.INIT }}$ and $[\mathrm{U}(\mathrm{VI})]_{\text {ORG.EQ denote the }}$ U(VI) concentrations in the initial organic and organic phase after re-extraction (at equilibrium conditions).

The concentration of U(VI) in the organic phases after re-extraction was determined from the difference in the U(VI) concentration in the aqueous phases after re-extraction (at equilibrium conditions) and stock solution taking into account the organic-to-aqueous $(\mathrm{O} / \mathrm{A})$ phase volume ratio: $[\mathrm{U}(\mathrm{VI})]_{\mathrm{ORG} . \mathrm{EQ}}=\left([\mathrm{U}(\mathrm{VI})]_{\mathrm{AQ} . \mathrm{EQ}}-[\mathrm{U}(\mathrm{VI})]_{\mathrm{AQ} . \mathrm{STRIP}}\right) /(\mathrm{O} / \mathrm{A})$ , where $[\mathrm{U}(\mathrm{VI})]_{\mathrm{AQ} . S T R I P}$ and $[\mathrm{U}(\mathrm{VI})]_{\mathrm{AQ} . \mathrm{EQ}}$ denote the $\mathrm{U}(\mathrm{VI})$ concentrations in the strip solution and aqueous phase after re-extraction (at equilibrium conditions).

Extraction of $\left[\left(\mathrm{UO}_{2}\right)_{2}\left(\mathrm{O}_{2}\right)\left(\mathrm{CO}_{3}\right)_{4}\right]^{6-}$ or $\left[\left(\mathrm{UO}_{2}\right)_{3}\left(\mathrm{O}_{2}\right)_{2}\left(\mathrm{CO}_{3}\right)_{4}\right]^{--}$with 
MTOA carbonate from carbonate solutions can be described by following chemical equations [12]-[14]:

$2\left(\mathrm{R}_{4} \mathrm{~N}\right)_{2} \mathrm{CO}_{3(\text { org })}+\mathrm{Na}_{4}\left[\mathrm{UO}_{2}\left(\mathrm{O}_{2}\right)_{x}\left(\mathrm{CO}_{3}\right)_{3-x}\right]($ aq $) \leftrightarrow$

$\leftrightarrow\left(\mathrm{R}_{4} \mathrm{~N}\right)_{4}\left[\mathrm{UO}_{2}\left(\mathrm{O}_{2}\right)_{x}\left(\mathrm{CO}_{3}\right)_{3-x}\right]$ (org) $+2 \mathrm{Na}_{2} \mathrm{CO}_{3}$ (aq)

$3\left(\mathrm{R}_{4} \mathrm{~N}\right)_{2} \mathrm{CO}_{3}$ (org) $+\mathrm{Na}_{6}\left[\left(\mathrm{UO}_{2}\right)_{2}\left(\mathrm{O}_{2}\right)\left(\mathrm{CO}_{3}\right)_{4}\right]_{(\mathrm{aq}) \leftrightarrow}$

$\leftrightarrow\left(\mathrm{R}_{4} \mathrm{~N}\right)_{6}\left[\left(\mathrm{UO}_{2}\right)_{2}\left(\mathrm{O}_{2}\right)\left(\mathrm{CO}_{3}\right)_{4}\right]$ (org) $+3 \mathrm{Na}_{2} \mathrm{CO}_{3}$ (aq)

$3\left(\mathrm{R}_{4} \mathrm{~N}\right)_{2} \mathrm{CO}_{3}$ (org) $+\mathrm{Na}_{6}\left[\left(\mathrm{UO}_{2}\right)_{3}\left(\mathrm{O}_{2}\right)_{2}\left(\mathrm{CO}_{3}\right)_{4}\right]_{(\mathrm{aq})} \leftrightarrow$

$\leftrightarrow\left(\mathrm{R}_{4} \mathrm{~N}\right)_{6}\left[\left(\mathrm{UO}_{2}\right)_{3}\left(\mathrm{O}_{2}\right)_{2}\left(\mathrm{CO}_{3}\right)_{4}\right](\mathrm{org})+3 \mathrm{Na}_{2} \mathrm{CO}_{3}(\mathrm{aq})$

where $\mathrm{R}_{4} \mathrm{~N}$ is a quaternary ammonium cation (MTOA).

To study the U(VI) re-extraction processes, individual organic phases with concentrations from $20 \mathrm{gU}(\mathrm{VI}) / \mathrm{L}$ to $140 \mathrm{gU}(\mathrm{VI}) / \mathrm{L}$ not containing other metals were obtained.

The content of U(VI) in the aqueous solutions with concentration over $1.0 \mathrm{~g} / \mathrm{L}$ was established by titration, using $8.4 \mathrm{mmol} / \mathrm{L}$ solution of ammonium vanadate as the titrant and diphenylamine-4-sulfonic acid sodium salt as the indicator [15]. The content of U(VI) in the solutions with concentration lower than $1.0 \mathrm{~g} / \mathrm{L}$ was established by the spectrophotometry method with Arsenazo III, per the absorbance spectra of the greenblue complex compound arsenazo-uranyl $\left(\lambda_{\max }=651 \mathrm{~nm}\right.$, detection limit $\left.\sim 0.025-0.05 \mu \mathrm{g} \mathrm{U} / \mathrm{L}\right)$ [16]. The relative error for the determination of the U(VI) concentration in the stock solutions and aqueous phases after re-extraction was not more than $0.5 \%$.

The phase content of the powders was established from the XRD data of the samples. The XRD spectra were obtained with a D2 PHASER Bruker. The spectra were analyzed, and the phase content was established using the PDF 2010 database and TOPAS structural refinement software.

\section{RESULTS AND DISCUSSION}

3.1. Re-extraction of uranium(VI) from the MTOA organic phase loaded by peroxo-carbonate species using aqueous solutions of $\left(\mathrm{NH}_{4}\right)_{2} \mathrm{CO}_{3}$

Re-extraction of U(VI) from the MTOA organic phase loaded by carbonate and mixed peroxocarbonate species without crystallization of AUC is possible when using the diluted $(<15 \% \mathrm{wt})$ solutions of $\left(\mathrm{NH}_{4}\right)_{2} \mathrm{CO}_{3}$. The process of U(VI) re-extraction under such conditions proceeds according to the anion exchange mechanism with distribution in the aqueous phase of mixed peroxo-carbonate species $\left(\mathrm{NH}_{4}\right)_{4}\left[\mathrm{UO}_{2}\left(\mathrm{O}_{2}\right)_{x}\left(\mathrm{CO}_{3}\right)_{3-x}\right],\left(\mathrm{NH}_{4}\right)_{6}\left[\left(\mathrm{UO}_{2}\right)_{2}\left(\mathrm{O}_{2}\right)\left(\mathrm{CO}_{3}\right)_{4}\right]$, and $\left(\mathrm{NH}_{4}\right)_{6}\left[\left(\mathrm{UO}_{2}\right)_{3}\left(\mathrm{O}_{2}\right)_{2}\left(\mathrm{CO}_{3}\right)_{4}\right]$ (composition was established by UV-Vis spectroscopy) and MTOA carbonate in the organic phase. The formation and crystallization of AUC in the aqueous phase, in this case, did not occur. To obtain concentrated U(VI)containing carbonate solutions after re-extraction and crystallization of AUC, it is necessary to use concentrated solutions $\left(\mathrm{NH}_{4}\right)_{2} \mathrm{CO}_{3}$ and to carry out a multistage countercurrent process at high $\mathrm{O} / \mathrm{A}$ ratios.

Table 1. Re-extraction of uranium(VI) from the MTOA organic phase loaded by peroxo-carbonate species, containing 136.o gU(VI)/L using $6 \%$ aqueous $\left(\mathrm{NH}_{4}\right)_{2} \mathrm{CO}_{3}$ solution. $\mathrm{O} / \mathrm{A}=1 / 1$, phase mixing time $(\tau)-60 \mathrm{~min}$. [U(VI)] $]_{\mathrm{AQ} . \mathrm{STRIP}}-$ concentration of $\mathrm{U}(\mathrm{VI})$ in the strip solution, $[\mathrm{U}(\mathrm{VI})]_{\mathrm{ORG} . \mathrm{EQ}}$ - equilibrium concentration of $\mathrm{U}(\mathrm{VI})$ in the organic phase, $[\mathrm{U}(\mathrm{VI})]_{\mathrm{AQ}} \mathrm{EQ}-$ equilibrium concentration of $\mathrm{U}(\mathrm{VI})$ in the aqueous phase

\begin{tabular}{|c|c|c|c|c|}
\hline № step & {$[\mathrm{U}(\mathrm{VI})]_{\text {AQ.STRIP, }} \mathrm{g} / \mathrm{L}$} & {$[\mathrm{U}(\mathrm{VI})]_{\text {ORG.EQ}}, \mathrm{g} / \mathrm{L}$} & {$[\mathrm{U}(\mathrm{VI})]_{\mathrm{AQ} . \mathrm{EQ}}, \mathrm{g} / \mathrm{L}$} & $\mathrm{Re}(\mathrm{U}(\mathrm{VI})), \%$ \\
\hline 1 & 0.0 & $30.0 \pm 0.27$ & $106.0 \pm 0.37$ & $77.9 \pm 0.62$ \\
\hline 2 & $106.0 \pm 0.37$ & $106.0 \pm 0.95$ & $136.0 \pm 0.54$ & $26.5 \pm 0.21$ \\
\hline 3 & $136.0 \pm 0.54$ & $125.0 \pm 0.88$ & $147.0 \pm 0.44$ & $8.1 \pm 0.06$ \\
\hline 4 & $147.0 \pm 0.44$ & $131.7 \pm 0.92$ & $151.3 \pm 0.45$ & $3.2 \pm 0.02$ \\
\hline
\end{tabular}

When used of $6 \%$ aqueous $\left(\mathrm{NH}_{4}\right)_{2} \mathrm{CO}_{3}$ solution for re-extraction of $\mathrm{U}(\mathrm{VI})$ from the organic phase containing $136 \mathrm{gU}(\mathrm{VI}) / \mathrm{L}$ in the form of peroxocarbonate species, the $\operatorname{Re}(\mathrm{U}(\mathrm{VI}))$ value for one step was made $77.9 \pm 0.62 \%$, Table 1 . Uranium(VI) concentration in the aqueous phase after re-extraction was $106 \mathrm{~g} / \mathrm{L}$. The aqueous phase was colored orange, which is characteristic of peroxo-carbonate species of U(VI). During successive stages of re-extraction with the same portion of $6 \%$ aqueous $\left(\mathrm{NH}_{4}\right)_{2} \mathrm{CO}_{3}$ solution for reextraction of fresh portions of U(VI)-loaded organic phase, accumulation of U(VI) takes place in the aqueous phase. The concentration of U(VI) after the four-step re-extraction mode was $151.3 \mathrm{~g} / \mathrm{L}$ and the crystallization of the carbonate complexes of U(VI) did not occur. However, the increase in the number of reextraction steps results in a decrease in the $\operatorname{Re}(\mathrm{U}(\mathrm{VI}))$ value at each subsequent step, which is associated with a decrease of the $\left(\mathrm{NH}_{4}\right)_{2} \mathrm{CO}_{3}$ concentration in the strip solution as a result of chemical interaction with the U(VI)-loaded organic phase, Table 1.
The results obtained confirm the assumption that the re-extraction under these conditions proceeds according to the anion exchange mechanism, as a result of which mixed peroxo-carbonate species of $\mathrm{U}(\mathrm{VI})$ are distributed into the aqueous phase. The solubility of this species is significantly higher than the solubility of AUC in carbonate solutions. The formation and crystallization of AUC, in this case, do not occur. High solubility of U(VI) peroxo-carbonate species in carbonate solutions leads to the obtaining of U(VI)containing solutions with high concentrations.

The re-extraction of U(VI) in the form of peroxocarbonate species according to the anion exchange mechanism can be expressed in the form of the following equations:

$$
\begin{aligned}
& \left(\mathrm{R}_{4} \mathrm{~N}\right)_{4}\left[\mathrm{UO}_{2}\left(\mathrm{O}_{2}\right)_{x}\left(\mathrm{CO}_{3}\right)_{3-x}\right]_{(\mathrm{org})}+2\left(\mathrm{NH}_{4}\right)_{2} \mathrm{CO}_{3(\mathrm{aq})} \leftrightarrow \\
\leftrightarrow & 2\left(\mathrm{R}_{4} \mathrm{~N}\right)_{2} \mathrm{CO}_{3}(\mathrm{org})+\left(\mathrm{NH}_{4}\right)_{4}\left[\mathrm{UO}_{2}\left(\mathrm{O}_{2}\right)_{x}\left(\mathrm{CO}_{3}\right)_{3-x}\right](\mathrm{aq})
\end{aligned}
$$

$\left(\mathrm{R}_{4} \mathrm{~N}\right)_{6}\left[\left(\mathrm{UO}_{2}\right)_{2}\left(\mathrm{O}_{2}\right)\left(\mathrm{CO}_{3}\right)_{4}\right]_{(\mathrm{org})}+3\left(\mathrm{NH}_{4}\right)_{2} \mathrm{CO}_{3}(\mathrm{aq}) \leftrightarrow$ $\leftrightarrow 3\left(\mathrm{R}_{4} \mathrm{~N}\right)_{2} \mathrm{CO}_{3}(\mathrm{org})+\left(\mathrm{NH}_{4}\right)_{6}\left[\left(\mathrm{UO}_{2}\right)_{2}\left(\mathrm{O}_{2}\right)\left(\mathrm{CO}_{3}\right)_{4}\right]_{(\mathrm{aq})}$ 
$\left(\mathrm{R}_{4} \mathrm{~N}\right)_{6}\left[\left(\mathrm{UO}_{2}\right)_{3}\left(\mathrm{O}_{2}\right)_{2}\left(\mathrm{CO}_{3}\right)_{4}\right]_{(\mathrm{org})}+3\left(\mathrm{NH}_{4}\right)_{2} \mathrm{CO}_{3}(\mathrm{aq}) \leftrightarrow$ $\leftrightarrow 3\left(\mathrm{R}_{4} \mathrm{~N}\right)_{2} \mathrm{CO}_{3}(\mathrm{org})+\left(\mathrm{NH}_{4}\right)_{6}\left[\left(\mathrm{UO}_{2}\right)_{3}\left(\mathrm{O}_{2}\right)_{2}\left(\mathrm{CO}_{3}\right)_{4}\right]_{(\mathrm{aq})}$

Increasing $\mathrm{O} / \mathrm{A}$ ratios from 1 to $5^{-3}$ leads to decrease in the $\operatorname{Re}(\mathrm{U}(\mathrm{VI}))$ value for one step from $77.9 \pm 0.62 \%$ to $5.7-16.7 \%$.

In the CARBEX process at the stage of uranium and plutonium re-extraction, it is necessary to obtain crystalline $\left(\mathrm{NH}_{4}\right)_{4}\left[\left(\mathrm{UO}_{2}\right)\left(\mathrm{CO}_{3}\right)_{3}\right] \quad$ and $\left(\mathrm{NH}_{4}\right)_{4}\left[\left(\mathrm{PuO}_{2}\right)\left(\mathrm{CO}_{3}\right)_{3}\right]$, which after drying are used to obtain powders $\mathrm{UO}_{2}$ and $\mathrm{PuO}_{2}$ suitable for the MOX fuel fabrication. Therefore, in the re-extraction process, it is necessary to create conditions for the high depth of uranium and plutonium crystallization in the form of $\mathrm{AUC} / \mathrm{APuC}$ mixture. To do this, it is necessary to provide conditions for decomposition of U(VI) peroxo-carbonate species in the carbonate solutions that have high solubility and make it difficult for $\mathrm{AUC} / \mathrm{APuC}$ crystallization to the re-extraction step.

To decomposition of stable peroxo-carbonate species of U(VI) in carbonate solutions and increase the degree of deposition of U(VI) in the form of AUC crystals, a carbonation method using gaseous carbon dioxide $\left(\mathrm{CO}_{2}(\mathrm{~g})\right)$ can be used. During bubbling of $\mathrm{CO}_{2}(\mathrm{~g})$ through the layer of the aqueous solution, carbonic acid $\left(\mathrm{H}_{2} \mathrm{CO}_{3}\right)$ is formed. This can lead to the hydrolysis of U(VI) peroxo-carbonate species and formation of slightly soluble species - uranyl carbonate $\left(\mathrm{UO}_{2} \mathrm{CO}_{3}\right)$ and polynuclear hydrolyzed species of $\mathrm{U}(\mathrm{VI})$ that can be also used to obtain uranium oxides. Another option for decomposition of the U(VI) peroxo- carbonate species may be to increase the concentration of $\left(\mathrm{NH}_{4}\right)_{2} \mathrm{CO}_{3}$ in the strip solution. In this case, the chemical equilibrium in the carbonate solutions should shift towards the formation of carbonate species, mainly the most stable AUC. With an excess of $\mathrm{CO}_{3}{ }^{2-}$ $/ \mathrm{HCO}_{3}-$ ions in carbonate solutions, there is a reaction of exchange of peroxide ligands $\left(\mathrm{O}_{2}{ }^{2-}\right)$ in the mixed peroxo-carbonate species of U(VI) into carbonate ligands. The products of these reactions are carbonate species of U(VI) whose composition corresponds to the general formulae $\left[\mathrm{UO}_{2}\left(\mathrm{CO}_{3}\right)_{x}\right]^{2-2 x}$, where $x=2$ or 3 . It should be noted that the formation of uranyl tricarbonate complex $\left[\mathrm{UO}_{2}\left(\mathrm{CO}_{3}\right)_{3}\right]^{4-}$ is most suitable because the solubility of uranyl dicarbonate complex $\left[\mathrm{UO}_{2}\left(\mathrm{CO}_{3}\right)_{2}\left(\mathrm{H}_{2} \mathrm{O}\right)_{2}\right]^{2-}$ is significantly higher and this leads to a decrease in the degree of deposition of U(VI) at precipitative re-extraction [17].

\subsection{Precipitative re-extraction of uranium(VI)}

from the MTOA organic phase loaded by peroxocarbonate species using $\left(\mathrm{NH}_{4}\right)_{2} \mathrm{CO}_{3}$ and $\mathrm{NH}_{4} \mathrm{HCO}_{3}$ in the presence of gaseous $\mathrm{CO}_{2}$

The study of $\mathrm{U}(\mathrm{VI})$ re-extraction in the $\mathrm{CO}_{2}(\mathrm{~g})$ media was carried out in two modes. According to the first mode, $\mathrm{CO}_{2}(\mathrm{~g})$ (with flow rate $0.5 \mathrm{~L} / \mathrm{min}$ ) was bubbled through the layer of aqueous-organic emulsion. According to the second mode, re-extraction was carried out in a steel autoclave with overpressure of $\mathrm{CO}_{2}(\mathrm{~g})\left(p\left(\mathrm{CO}_{2}\right)\right)$ equal to $5 \mathrm{~atm}$.

Table 2. Re-extraction of uranium(VI) from the MTOA organic phase loaded by peroxo-carbonate species, using $\left(\mathrm{NH}_{4}\right)_{2} \mathrm{CO}_{3}$ and $\mathrm{NH}_{4} \mathrm{HCO}_{3}$ aqueous solutions in the presence of gaseous $\mathrm{CO}_{2}$. [U(VI)] ORG.INIT - concentration of U(VI) in the initial organic solution.

\begin{tabular}{|c|c|c|c|c|c|c|c|}
\hline № & Conditions & Reagent & $\mathrm{O} / \mathrm{A}$ & $\begin{array}{c}{[\mathrm{U}(\mathrm{VI})]_{\mathrm{ORG}} \text { INIT }} \\
\mathrm{g} / \mathrm{L}\end{array}$ & $\begin{array}{c}\text { [U(VI) }]_{\text {ORG. EQ }}, \\
\mathrm{g} / \mathrm{L}\end{array}$ & $\begin{array}{c}{[\mathrm{U}(\mathrm{VI})]_{\mathrm{AQ} \cdot \mathrm{EQ}}} \\
\mathrm{g} / \mathrm{L}\end{array}$ & $\begin{array}{c}\operatorname{Re}(\mathrm{U}(\mathrm{VI})), \\
\%\end{array}$ \\
\hline 1 & \multirow{3}{*}{$\begin{array}{c}\text { Bubbling of } \\
\mathrm{CO}_{2}(\mathrm{~g}) \\
\text { (flow rate } \\
0.5 \mathrm{~L} / \mathrm{min} \text { ) }\end{array}$} & $20 \%\left(\mathrm{NH}_{4}\right)_{2} \mathrm{CO}_{3}$ & \multirow{2}{*}{$1 / 1$} & $22.5 \pm 0.09$ & $0.4 \pm 0.001$ & $22.1 \pm 0.08$ & $98.2 \pm 0.69$ \\
\hline 2 & & $10 \% \mathrm{NH}_{4} \mathrm{HCO}_{3}$ & & $25.6 \pm 0.07$ & $2.6 \pm 0.008$ & $23.0 \pm 0.08$ & $89.8 \pm 0.63$ \\
\hline 3 & & \multirow{2}{*}{$10 \%\left(\mathrm{NH}_{4}\right)_{2} \mathrm{CO}_{3}$} & $2 / 1$ & $19.5 \pm 0.04$ & $10.0 \pm 0.04$ & $27 \cdot 3 \pm 0.11$ & $48.7 \pm 0.39$ \\
\hline 4 & $p\left(\mathrm{CO}_{2}\right)=5 \mathrm{~atm}$ & & \multirow{2}{*}{$1 / 1$} & $21.8 \pm 0.07$ & $0.5 \pm 0.003$ & $21.3 \pm 0.12$ & $97.7 \pm 0.69$ \\
\hline 5 & (in autoclave) & $1 \%\left(\mathrm{NH}_{4}\right)_{2} \mathrm{CO}_{3}$ & & $21.8 \pm 0.07$ & $21.3 \pm 0.06$ & $0.5 \pm 0.01$ & $2.3 \pm 0.02$ \\
\hline
\end{tabular}

Table 3. Re-extraction of uranium(VI) from the MTOA organic phase loaded by peroxo-carbonate species, containing 136.0 $\mathrm{gU}(\mathrm{VI}) / \mathrm{L}$ using $6 \%$ aqueous $\left(\mathrm{NH}_{4}\right)_{2} \mathrm{CO}_{3}$ solution in the presence of gaseous $\mathrm{CO}_{2}$ (flow rate $0.5 \mathrm{~L} / \mathrm{min}$ ). $\mathrm{O} / \mathrm{A}=1 / 1, \tau-120 \mathrm{~min}$

\begin{tabular}{|c|c|c|c|c|}
\hline No step & {$[\mathrm{U}(\mathrm{VI})]_{\text {ORG. INIT, } \mathrm{g} / \mathrm{L}}$} & {$[\mathrm{U}(\mathrm{VI})]_{\mathrm{ORG} . \mathrm{QQ}}, \mathrm{g} / \mathrm{L}$} & {$[\mathrm{U}(\mathrm{VI})]_{\mathrm{AQ} . \mathrm{EQ}}, \mathrm{g} / \mathrm{L}$} & $\mathrm{Re}(\mathrm{U}(\mathrm{VI})), \%$ \\
\hline 1 & $136.0 \pm 0.55$ & $36.0 \pm 0.15$ & $60.0 \pm 0.26$ & $73.5 \pm 0.58$ \\
\hline 2 & $36.0 \pm 0.14$ & $15.0 \pm 0.06$ & $6.0 \pm 0.03$ & $58.3 \pm 0.52$ \\
\hline
\end{tabular}

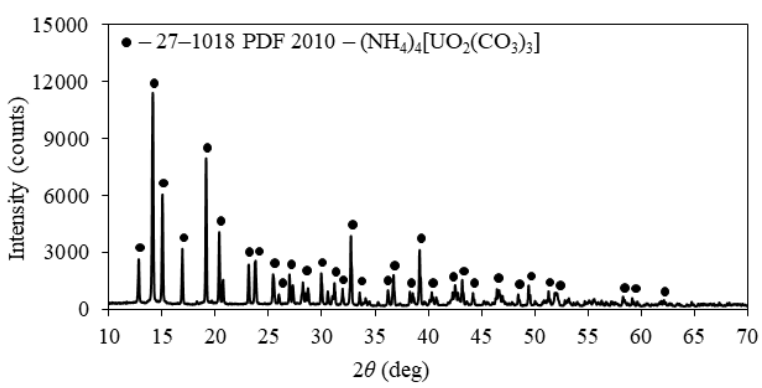

Figure 2. XRD pattern of carbonate precipitate after re-extraction of U(VI) from organic phase containing $22.5 \mathrm{gU}(\mathrm{VI}) / \mathrm{L}$ with $20 \%\left(\mathrm{NH}_{4}\right)_{2} \mathrm{CO}_{3}$ solution in the presence of $\mathrm{CO}_{2}(\mathrm{~g})$
The formation of AUC crystals during the reextraction process was observed only if $20 \%$ solution $\left(\mathrm{NH}_{4}\right)_{2} \mathrm{CO}_{3}$ was used. The formation of a bright yellow precipitate occurred after $10 \mathrm{~min}$ of $\mathrm{CO}_{2}(\mathrm{~g})$ bubbling. The crystallization of AUC shifts the equilibrium of the system towards the extraction of U(VI) from the organic phase into the carbonate solution. The $\operatorname{Re}(\mathrm{U}(\mathrm{VI}))$ value, in this case, was more than $98 \%$, Table 2. The obtained carbonate precipitate was monophasic crystalline $\left(\mathrm{NH}_{4}\right)_{4}\left[\left(\mathrm{UO}_{2}\right)\left(\mathrm{CO}_{3}\right)_{3}\right]$ powder, Figure 2.

Decrease of $\left(\mathrm{NH}_{4}\right)_{2} \mathrm{CO}_{3}$ concentration from $20 \%$ to $10 \%$ and increase of $\mathrm{O} / \mathrm{A}$ ratio from $1 / 1$ to $3 / 1$ resulted in decrease of $\operatorname{Re}(\mathrm{U}(\mathrm{VI}))$ value from $98.2 \pm 0.69 \%$ to $48.7 \pm 0.39 \%$, Table 2 . The only product (by XRD data) 
of AUC thermal decomposition in an oxygen atmosphere at $750^{\circ} \mathrm{C}$ for $4 \mathrm{hrs}$ was triuranium octaoxide $\left(\mathrm{U}_{3} \mathrm{O}_{8}\right)$.

An increase of $\operatorname{Re}(\mathrm{U}(\mathrm{VI}))$ value in the presence of $\mathrm{CO}_{2}(\mathrm{~g})$ is associated with the formation of $\mathrm{H}_{2} \mathrm{CO}_{3}$ :

$$
\mathrm{CO}_{2(\mathrm{~g})}+\mathrm{H}_{2} \mathrm{O} \leftrightarrow \mathrm{H}_{2} \mathrm{CO}_{3}(\mathrm{aq})
$$

Carbonic acid catalyzes the decomposition processes of $\mathrm{U}(\mathrm{VI})$ mixed peroxo-carbonate species:

$$
\begin{aligned}
& \left(\mathrm{NH}_{4}\right)_{4}\left[\mathrm{UO}_{2}\left(\mathrm{O}_{2}\right)_{x}\left(\mathrm{CO}_{3}\right)_{3-x}\right]_{(\mathrm{aq})}+x \mathrm{H}_{2} \mathrm{CO}_{3}(\mathrm{aq}) \\
& \rightarrow\left(\mathrm{NH}_{4}\right)_{4}\left[\mathrm{UO}_{2}\left(\mathrm{CO}_{3}\right)_{3}\right]_{(\mathrm{aq})}+x \mathrm{H}_{2} \mathrm{O}_{2}(\mathrm{aq})
\end{aligned}
$$

where $x=1$ or 2 .

In the presence of $\mathrm{CO}_{2}(\mathrm{~g})$ also the formation of $\mathrm{NH}_{4} \mathrm{HCO}_{3}$ :

$$
\left(\mathrm{NH}_{4}\right)_{2} \mathrm{CO}_{3}(\mathrm{aq})+\mathrm{CO}_{2(\mathrm{~g})} \rightarrow 2 \mathrm{NH}_{4} \mathrm{HCO}_{3}(\mathrm{aq})
$$

The main decomposition product of the U(VI) peroxo-carbonate species is AUC, whose degree of deposition is increased in the presence of $\mathrm{CO}_{2}(\mathrm{~g})$. Hydrogen peroxide released into the carbonate solution according to equation 10 is completely decomposed within $10-15$ min to form $\mathrm{H}_{2} \mathrm{O}$ and $\mathrm{O}_{2}$. Products of $\left[\mathrm{UO}_{2}\left(\mathrm{CO}_{3}\right)_{3}\right]^{4-}$ and $\left[\mathrm{UO}_{2}\left(\mathrm{CO}_{3}\right)_{2}\right]^{2-}$ hydrolysis in the presence of $\mathrm{H}_{2} \mathrm{CO}_{3}$ may be
The total $\operatorname{Re}(\mathrm{U}(\mathrm{VI}))$ value equal to $89 \%$ was achieved in two successive re-extraction steps under bubbling of $\quad \mathrm{CO}_{2}(\mathrm{~g}), \quad$ Table 3. polynuclear hydrolyzed species of $\mathrm{U}(\mathrm{VI})$ and $\mathrm{UO}_{2} \mathrm{CO}_{3}$ [18]. The hydrolysis reaction equation of the carbonate species of U(VI) in the presence of $\mathrm{H}_{2} \mathrm{CO}_{3}$ can be written as follows:

$$
\begin{aligned}
& \left(\mathrm{NH}_{4}\right)_{2 x-2}\left[\mathrm{UO}_{2}\left(\mathrm{CO}_{3}\right)_{x}\right](\mathrm{aq})+(x-1) \mathrm{H}_{2} \mathrm{CO}_{3(\mathrm{aq})} \\
& \rightarrow \mathrm{UO}_{2} \mathrm{CO}_{3(\mathrm{~s})}+(x-1) \mathrm{NH}_{4} \mathrm{HCO}_{3(\mathrm{aq})}
\end{aligned}
$$

where $x=2$ or 3 .

Uranyl carbonate and other hydrolyzed species may also serve as suitable initial materials for the production of $\mathrm{UO}_{2}$ and $\mathrm{U}_{3} \mathrm{O}_{8}$. However, the hydrolysis of AUCs in the systems under investigation does not appear to proceed. In the crystalline carbonate precipitates composition formed during re-extraction for all systems studied in the work, no phases other than AUC were found (according to the XRD analysis data).

Increasing the $\left(\mathrm{NH}_{4}\right)_{2} \mathrm{CO}_{3}$ concentration from $6 \%$ to $20 \%$ does not significantly increase the $\operatorname{Re}(\mathrm{U}(\mathrm{VI}))$ value. For two steps, the total value of $\operatorname{Re}(\mathrm{U}(\mathrm{VI}))$ was $90.8 \%$, Table 4 .

Table 4. Re-extraction of uranium(VI) from the MTOA organic phase loaded by peroxo-carbonate species, containing $87.3 \mathrm{gU}(\mathrm{VI}) / \mathrm{L}$ using $20 \%$ aqueous $\left(\mathrm{NH}_{4}\right)_{2} \mathrm{CO}_{3}$ solution in the presence of gaseous $\mathrm{CO}_{2}$ (flow rate $0.5 \mathrm{~L} / \mathrm{min}$ ). $\mathrm{O} / \mathrm{A}=1 / 1, \tau-60 \mathrm{~min}$

\begin{tabular}{|c|c|c|c|c|}
\hline No step & [U(VI) $]_{\text {org.INIT, }, \mathrm{L} / \mathrm{L}}$ & {$[\mathrm{U}(\mathrm{VI})]_{\mathrm{ORG} . \mathrm{EQ}, \mathrm{g} / \mathrm{L}}$} & {$[\mathrm{U}(\mathrm{VI})]_{\mathrm{AQ} . \mathrm{EQ}}, \mathrm{g} / \mathrm{L}$} & $\mathrm{Re}(\mathrm{U}(\mathrm{VI})), \%$ \\
\hline 1 & $87.3 \pm 0.35$ & $39.6 \pm 0.16$ & $43.8 \pm 0.16$ & $54.6 \pm 0.44$ \\
\hline 2 & $39.6 \pm 0.19$ & $8.0 \pm 0.03$ & $6.4 \pm 0.02$ & $79.8 \pm 0.72$ \\
\hline
\end{tabular}

When used $20 \% \quad\left(\mathrm{NH}_{4}\right)_{2} \mathrm{CO}_{3}$ solution, a wellcrystallized AUC is formed. An increase of the $\left(\mathrm{NH}_{4}\right)_{2} \mathrm{CO}_{3}$ concentration leads to an increase of the concentration of $\mathrm{NH}_{4} \mathrm{HCO}_{3}$ in the systems with $\mathrm{CO}_{2}(\mathrm{~g})$ (equation 11). The solid carbonate products of reextraction in such cases were a mixture of AUC and $\mathrm{NH}_{4} \mathrm{HCO}_{3}$.

At the same time, in the case of re-extraction with $10 \mathrm{~mol} / \mathrm{L}\left(\mathrm{NH}_{4}\right)_{2} \mathrm{CO}_{3}$ solution at $\mathrm{O} / \mathrm{A}=1 / 1$ and phase mixing time of $15 \mathrm{~min}$, the $\operatorname{Re}(\mathrm{U}(\mathrm{VI}))$ value is reached 99.1-99.5\%. The degree deposition of U(VI) was 99.4$99.7 \%$. Losses of U(VI) at the re-extraction stage (mainly with carbonate solution) amounted to $\sim 0.5 \%$. The concentration of U(VI) in the organic phase after re-extraction was $0.028-0.03 \mathrm{~g} / \mathrm{L}$.

Similar behavior with uranium under re-extraction conditions is also shown by plutonium, which goes into the organic phase together with uranium depending on the valence state in the form of carbonate species $\left(\mathrm{R}_{4} \mathrm{~N}\right)_{4}\left[\mathrm{Pu}{ }^{(\mathrm{VI})} \mathrm{O}_{2}\left(\mathrm{CO}_{3}\right)_{3}\right]$ and $\left(\mathrm{R}_{4} \mathrm{~N}\right)_{4}\left[\mathrm{Pu}^{(\mathrm{IV})}\left(\mathrm{CO}_{3}\right)_{4}\right]$. In the conditions of precipitative re-extraction with use of $\left(\mathrm{NH}_{4}\right)_{2} \mathrm{CO}_{3}$ aqueous solutions, plutonium together with uranium distribution from an organic phase into carbonate solution in the form of carbonate species $\left(\left(\mathrm{NH}_{4}\right)_{4}\left[\mathrm{Pu}{ }^{(\mathrm{VI})} \mathrm{O}_{2}\left(\mathrm{CO}_{3}\right)_{3}\right], \quad\left(\left(\mathrm{NH}_{4}\right)_{4}\left[\mathrm{Pu}^{(\mathrm{IV})}\left(\mathrm{CO}_{3}\right)_{4}\right] \cdot 4 \mathrm{H}_{2} \mathrm{O}\right)\right.$ which crystallize together with AUC and formation of a homogenous mixture. The degree of plutonium reextraction under the optimal conditions established earlier for uranium is more than $99 \%$, and the degree of deposition is at least $98 \%$. A mixture of carbonate compounds of uranium and plutonium is filtered, washed, dried, and further calcined to $\mathrm{UO}_{2}$ and $\mathrm{PuO}_{2}$ in a reducing atmosphere. A mixture of uranium and plutonium dioxide is can be used for the fabrication of MOX fuel.

\section{CONCLUSION}

Based on the research of various options for U(VI) re-extraction from organic solutions of methyltrioctilammonium uranyl peroxo-carbonate complexes, the following conclusions may be formulated:

1) Re-extraction of U(VI) from MTOA extracts loaded with peroxo-carbonate complexes of U(VI) can be carried out in the form of two options: liquid-liquid phase or liquid-solid phase. Both of these options follow an anionic exchange mechanism. However, in the case of liquid-solid phase (precipitative mode) reextraction, the processes of the decomposition of U(VI) peroxo-carbonate compounds and crystallization of $\left(\mathrm{NH}_{4}\right)_{4}\left[\left(\mathrm{UO}_{2}\right)\left(\mathrm{CO}_{3}\right)_{3}\right]$ in the aqueous phase after recovery of U(VI) from the organic phase occur.

2) In case of use of diluted ( $<15 \% \mathrm{wt})$ solutions of $\left(\mathrm{NH}_{4}\right)_{2} \mathrm{CO}_{3}$, only the anion exchange of the mixed peroxo-carbonate complexes in the organic phase and $\mathrm{CO}_{3}{ }^{2-}$ anions are observed. In such systems, there is no decomposition of the U(VI) peroxo-carbonate complexes and crystallization of $\left(\mathrm{NH}_{4}\right)_{4}\left[\left(\mathrm{UO}_{2}\right)\left(\mathrm{CO}_{3}\right)_{3}\right]$ in the carbonate solution.

3) In the concentrated solutions of $\left(\mathrm{NH}_{4}\right)_{2} \mathrm{CO}_{3}$ there is the replacement of peroxide ligand $\left(\mathrm{O}_{2}{ }^{2-}\right)$ by $\mathrm{CO}_{3}{ }^{2-}$ ligand in the internal coordination sphere of the mixed 
peroxo-carbonate complexes of $\mathrm{U}(\mathrm{VI})$ $\left(\left[\mathrm{UO}_{2}\left(\mathrm{O}_{2}\right)_{x}\left(\mathrm{CO}_{3}\right)_{3-x}\right]^{4-}, \quad\left[\left(\mathrm{UO}_{2}\right)_{2}\left(\mathrm{O}_{2}\right)\left(\mathrm{CO}_{3}\right)_{4}\right]^{6-}\right.$, $\left.\left[\left(\mathrm{UO}_{2}\right)_{3}\left(\mathrm{O}_{2}\right)_{2}\left(\mathrm{CO}_{3}\right)_{4}\right]^{6-}\right)$ which were removed from an organic phase. As a result, carbonate complex $\left[\mathrm{UO}_{2}\left(\mathrm{CO}_{3}\right)_{3}\right]^{4^{-}}$is formed. The solubility of $\left(\mathrm{NH}_{4}\right)_{4}\left[\left(\mathrm{UO}_{2}\right)\left(\mathrm{CO}_{3}\right)_{3}\right]$ is significantly lower than the solubility of the mixed peroxo-carbonate compounds of $\mathrm{U}(\mathrm{VI})$ and depends on the concentration of $\left(\mathrm{NH}_{4}\right)_{2} \mathrm{CO}_{3}$ in the carbonate solution. Therefore, in concentrated solutions of $\left(\mathrm{NH}_{4}\right)_{2} \mathrm{CO}_{3}$ the value of the degree of U(VI) deposition was $99.4-99.7 \%$ and re-extraction yield was 99.1-99.5\%.

4) Use of gas carbonation process in the presence of carbon dioxide gas allows catalyzing the decomposition of mixed peroxo-carbonate complexes of U(VI) in aqueous phase and increasing of U(VI) re-extraction yield. However, in the $\mathrm{CO}_{2}$ (gas)-containing carbonate systems, crystals of $\left(\mathrm{NH}_{4}\right)_{4}\left[\left(\mathrm{UO}_{2}\right)\left(\mathrm{CO}_{3}\right)_{3}\right]$ may be contaminated with $\mathrm{NH}_{4} \mathrm{HCO}_{3}$.

The results obtained in the work make it possible to develop a process of precipitative re-extraction of $\mathrm{U}(\mathrm{VI})$ in the form of AUC crystals for the new alternative hydrochemical approach of spent nuclear fuel reprocessing (CARBEX).

Acknowledgments: The work was carried out with the financial support of the Russian Science Foundation. Grant number 20-63-46006.

\section{REFERENCES}

1. S. I. Stepanov, A. M. Chekmarev, "Concept of spent nuclear fuel reprocessing," Dokl. Chem., vol. 423, no. 1, pp. $276-278,2008$. https://doi.org/10.1134/S0012500808110037

2. G. S. Goff et al., "Development of a novel alkaline based process for spent nuclear fuel recycling", AIChE Annual Meeting, Nuclear Engineering Division, Salt Lake City (Utah), USA, Nov. 4-9, 2007.

3. N. Asanuma, M. Harada, Y. Ikeda, H. Tomiyasu, "New approach to the nuclear fuel reprocessing in non-acidic aqueous solutions," J. Nucl. Sci. Technol., vol. 38, no. 10, pp. 866-871, 2001.

https://doi.org/10.1080/18811248.2001.9715107

4. K. W. Kim et al., "Development of a treatment process and immobilization method for the volume reduction of uranium-bearing spent catalysts for final disposal," J. Nucl. Sci. Tech., vol. 55, no. 12, pp. 1459-1472, 2018. https://doi.org/10.1080/00223131.2018.1516578

5. C.Z. Soderquist et al., "Dissolution of irradiated commercial $\mathrm{UO}_{2}$ fuels in ammonium carbonate and hydrogen peroxide," Ind. Eng. Chem. Res., vol. 50, no. 4, pp. 1813-1818, 2011. https://doi.org/10.1021/ie101386n

6. С. И. Степанов, А. М. Чекмарёв, “Экстракция редких металлов солями четвертичных аммониевых оснований," Москва, Россия: ИздАТ, 2004.

(S. I. Stepanov, A. M. Chekmarev, Extraction of rare metals by the salts of quaternary ammonium bases, Moscow, Russia: IzdAT, 2004.)
7. V. Baran, F. Škvor, V. Voseček, "Formation of the ammonium-uranyl-carbonate complexes of the type $\left(\mathrm{NH}_{4}\right)_{4}\left[\mathrm{UO}_{2}\left(\mathrm{CO}_{3}\right)_{3}\right]$, prepared by precipitative re-extraction," Inorg. Chim. Acta, vol. 81, pp. 83-89, 1984. https://doi.org/10.1016/Soo20-1693(00)88739-3

8. S. Chegrouche, A. Kebir, "Study of ammonium uranyl carbonate re-extraction-crystallization process by ammonium carbonate," Hydrometallurgy, vol. 28, no. 2, pp. 135-147, 1992. https://doi.org/10.1016/0304-386X(92)90126-K

9. Ю.А. Ревенко и др., "Способ переработки облученного ядерного топлива,” патент RU2366012, Россия, Публ. 27.08.2009.

(Yu. A. Revenko et al., "Method of irradiated nuclear fuel treatment," patent RU2366012, Russia, Publ. 08.27.2009.)

10. B. Yahi, A. Kebir, "Influence of process re-extractioncrystallization parameters on the properties of ammonium uranyl-tricarbonate crystals," Hydrometallurgy, vol. 34, no. 1, pp. 65-78, 1993. https://doi.org/10.1016/0304-386X(93)90081-N

11. I. I. Chernyaev, Complex compounds of uranium, New York (NY), USA: Daniel Davey \& Co., Ink., 1966.

12. S. I. Stepanov et al. "CARBEX process, a new technology of reprocessing of spent nuclear fuel," Russ. J. Gen. Chem., vol. 81, no. 9, pp. 1949-1959, 2011. https://doi.org/10.1134/S1070363211090404

13. S. I. Stepanov, A. V. Boyarincev, A. A. Chehlov, A. M. Chekmarev, A. Yu. Tsivadze, "Chemistry of the CARBEX process. Identification of the absorption bands of the ligands in the electronic spectra of U(VI) extracts with methyltrioctylammonium carbonate," Dokl. Chem., vol. 473, no. 1, pp. 63-66, 2017. https://doi.org/10.1134/So012500817030065

14. A. V. Boyarintsev et al., "Separation of uranium(VI) and americium(III) by extraction from $\mathrm{Na}_{2} \mathrm{CO}_{3}-\mathrm{H}_{2} \mathrm{O}_{2}$ solutions using methyltrioctylammonium carbonate in toluene," Solvent Extr. Ion Exch., vol. 39, no. 7, pp. $745-763,2021$. https://doi.org/10.1080/07366299.2021.1876993

15. В. К. Марков, А. В. Виноградов, С. В. Елинсон, Уран, методы его определения, Москва, Россия: Атомиздат, 1960

(V. K. Markov, E. A. Vernyi, A. V. Vinogradov, Uranium, methods of its definition, Moscow, Russia: Atomizdat, 1960.)

16. Analytical Spectroscopy Library Volume 10 : Separation, preconcentration, and spectrophotometry in inorganic analysis, Z. Marczenko, M. Balcerzak, Eds., 1st ed., New York (NY), USA: Elsevier Science, 2000.

17. Н. С. Тураев, И. И. Жерин, Химия и технология урана, Москва, Россия: ЦНИИАТОМИНФОРМ, 2005.

(N. S. Turaev, I. I. Gerin, Chemistry and uranium technology, Moscow, Russia: TSNIYATOMINFORM, 2005.)

18. А. К. Бабко, В. С. Коденская, "Равновесия в растворе карбонатных комплексов уранила,” ЖHX, т. 5 , но. 11 , c. $2568-2574,1960$.

(A. S. Babko, V. S. Kodenskaya, "Study of equilibria in a solution of uranyl carbonate complexes," Russ. J. Inorg. Chem., vol. 5, no. 11, pp. 2568-2574, 1960.) 